
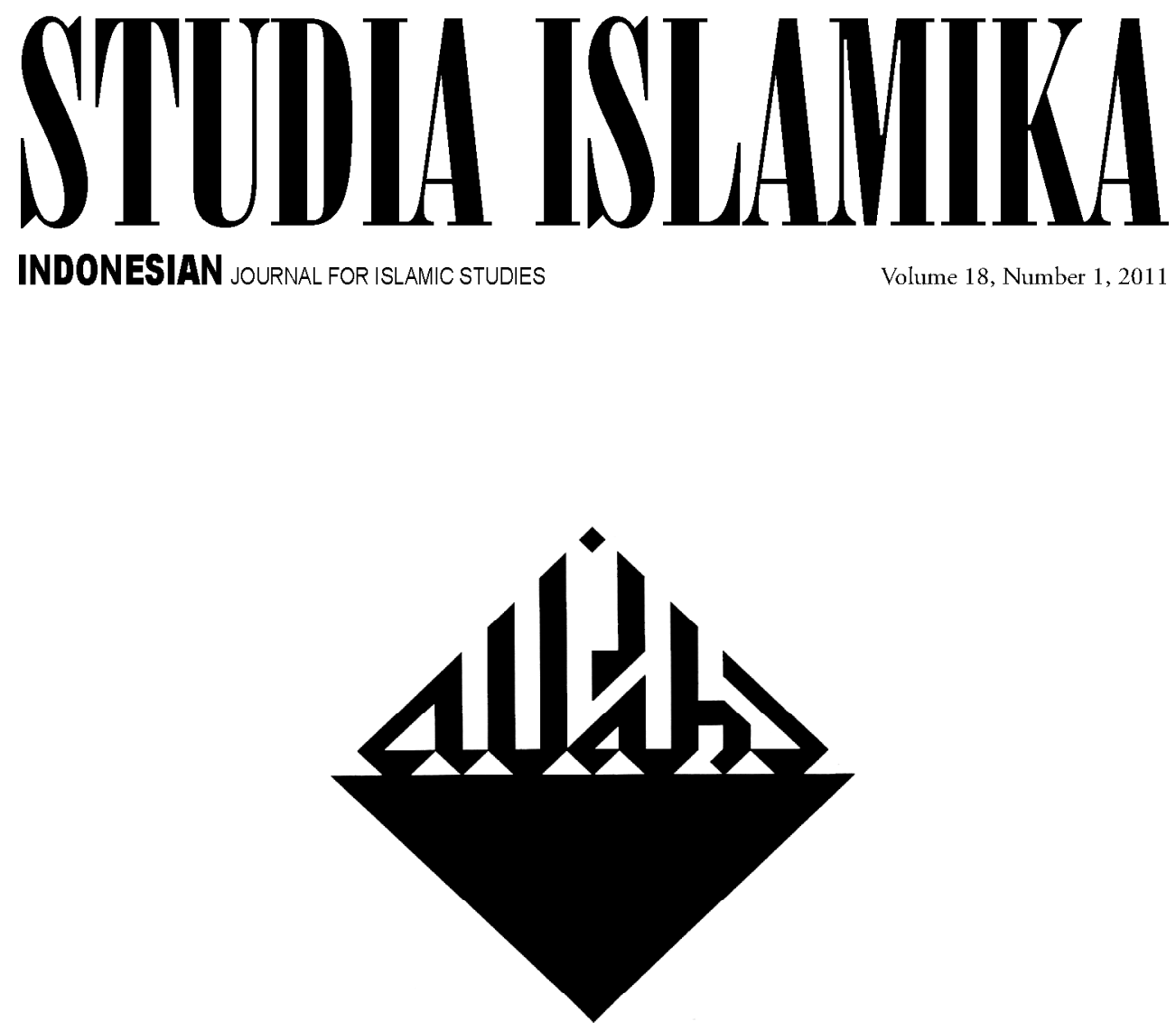

ECLECTICISM OF MODERN ISLAM:

ISLAM HADHARI IN MALAYSIA

Muhamad Ali

The Problems of Translation in TURjumãn al-Mustafíd: A Study of Theological and Eschatological Aspects Ervan Nurtawab

Islam, Historical Representation and Muslim Autobiography in the Indonesian New Order Mohamad Abdun Nasir 


\section{STIDIA ISLAVIIKA}




\section{STIIDIA ISLAIIIKL \\ Indonesian Journal for Islamic Studies \\ Vol. 18. no. 1.2011}

EDITORIAL BOARD:

M. Quraish Shihab (UIN Syarif Hidayatullah Jakarta)

Taufik Abdullah (LIPI Jakarta)

Nur A. Fadhil Lubis (IAIN Sumatra Utara)

M.C. Ricklefs (National University of Singapore)

Martin van Bruinessen (Utrecht University)

John R. Bowen (Washington University, St. Louis)

M. Atho Mudzhar (UIN Syarif Hidayatullah Jakarta)

M. Kamal Hasan (International Islamic University, Kuala Lumpur)

M. B. Hooker (Australian National University, Canberra)

Virginia M. Hooker (Australian National University, Canberra)

EDITOR-IN-CHIEF

Azyumardi Azra

\section{EDITORS}

Saiful Mujani

Jambari

Jajat Burhanudin

Oman Fathurahman

Ali Munhanif

Ismatu Ropi

Dina Afrianty

ASSISTANT TO THE EDITORS

Testriono

Muhammad Nida' Fadlan

ENGLISH LANGUAGE ADVISOR

Melissa Crouch

ARABIC LANGUAGE ADVISOR

Arrazy Hasyim

COVER DESIGNER

S. Prinka

STUDIA ISLAMIKA (ISSN 0215-0492) is a journal published by the Center for the Study of Istam and Society (PPIM) UIN Syarif Hidayatullath, Jakaria (STT DEPPEN No. 129/SK/DITJEN/PPG/ STT/1976). It specializes in Indonesian Islamic studies in particular, and South-east Asian Islamic Studies in general, and is intended to communicate original researches and current isstes on the subject. This journal warmly welcomes contributions from scholars of related disciplines.

All articles published do not necessarily represent the views of the journal, or other institutions to which it is affliated. They are solely the views of the authors. The articles contained in this journal have been refereed by the Board of Editors.

STUDIA ISLAMIKA has been accredited by The Ministry of National Education, Republic of Indonesia as an academic journal (SK Dirjen Dikti No. 83/Dikti/Kepi2009). 


\section{(C) Copyright Reserved}

\section{Editorial Office:}

STUDIA ISLAMIKA, Gedung Pusat Pengkajian Islam dan Masyarakat (PPIM) UIN Jakarta, Jl. Kertamukti No. 5, Pisangan Barat, Cirendeu, Ciputat 15419, Jakarta, Indonesia.

Phone: (62-21) 7423543, 7499272, Fax: (62-21) 7408633; E-mail: studia@ppim.or.id or studia.ppim@gmail.com. Website: www.ppim.or.id

Annual subscription rates from outside Indonesia: US\$ 130,00 . The cost of a single copy ordered from outside Indonesia is US\$50,00. Rates do not include international postage and handling.

Please make all payment through bank transfer to: PPIM, Bank Mandiri Jakarta, Indonesia, account No. 101-00-

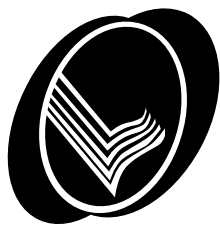
0514550-1 (USD), Swift Code: beiiidjaaxx

Harga berlangganan di Indonesia, satu tahun: Rp 130.000,-. Harga satu edisi Rp 50.000,-. Harga belum termasuk ongkos kirim. Pembayaran melalui PPIM, Bank Mandiri Jakarta, No. Rek: 128-00-0105080-3 


\section{Table of Contents}

\section{Articles}

$1 \quad$ Muhamad Ali

Eclecticism of Modern Islam: Islam Hadhari in Malaysia

33 Ervan Nurtawab

The Problems of Translation in Turjumān al-Mustafid:

A Study of Theological and Eschatological Aspects

67 Mohamad Abdun Nasir

Islam, Historical Representation and Muslim

Autobiography in the Indonesian New Order

101 Arrazy Hasyim

al-Tarīqah al-Naqshabandīyah fì Minangkabau:

Tarjamat Kitāb al-Sa'ädah al-Abadìyah

li Shaykh 'Abd al-Qadīm

139 Zuriyati

Hikāyat al-Sha'bīyah al-Minangkabāwīyah

Bundo Kanduang bayn al-Usțūrah

wa-al-Khurāfah: al-Manẓurah al-Dīnīyah

\section{Book Review}

167 Abmad Tholabi Kharlie

Modernisasi, Tradisi, dan Identitas:

Praktik Hukum Keluarga Islam Indonesia 


\section{Document}

199 Testriono

Is Indonesian Islam Different? Islam in Indonesia in a Comparative International Perspective 


\section{Is Indonesian Islam Different?}

Islam in Indonesia in a Comparative International Perspective

\section{Testriono}

enter for the Study of Islam and Society (Pusat Pengkajian
Islam dan Masyarakat, PPIM) of the State Islamic University
(UIN) Syarif Hidayatullah Jakarta in cooperation with Leiden University, the Netherlands, the Embassy of the Kingdom of the Netherlands (Ministry of Foreign Affairs, the Netherlands), and the Ministry of Religious Affairs, Indonesia, held an international conference called: 'Is Indonesian Islam Different? Islam in Indonesia in a Comparative International Perspective' on January 24-26, 2011 in Bogor, West Java.

This is the third international conference organized by INIS (Indonesian- Netherlands Co-operation in Islamic Studies) as part of its program on 'Training Indonesia's Young Leaders: Muslim Intellectuals as Agents of Change' which has begun in 2006. The program provides education and training for young Indonesian Muslim leaders. It also supports the participation of young Indonesia's Muslim leaders to participate at (international) conferences and to publish their research in international publication. The two successful international conferences that had been organized by INIS were 'Muslim Youth as Agents of Change in Indonesia' in 2007 and 'Islam and Democracy and Good Governance in Indonesia' in 2009.

This time the conference was opened by keynote speeches given by Professor Taufik Abdullah of Indonesian Institute of Sciences (LIPI) 
and Professor Robert W. Hefner of Institute on Culture, Religion, and World Affairs, Boston University. At the plenary session, Professor Azyumardi Azra of Graduate School at UIN Jakarta, Professor Bahtiar Effendy of the Faculty of Political and Social Science (FISIP) UIN Jakarta, and Professor Kees van Dijk of Leiden University delivered their lectures. The conference is divided into eighteen panels which include: political Islam, the Indonesia legal system, local manifestations of Islam, law at work, popular culture, feminism, rituals, radicalism, religious minorities, health and environment, contemporary manifestations of Islam, texts and society, students: politics and attitudes, sexuality, ulama, religious engineering, social affairs, female religious leadership.

Indonesian Islam is often regarded as peripheral, marginal and a deviation from what is labeled as the 'true' or 'pure' Islam in the Middle East. Indonesia is a country with the largest Muslim population in the world with a number of more than 200 million. Indonesian Islam has its distinct local coloring, but at the same time it has a strong, century's old, indigenous tradition of Islamic learning and scholarly production which is firmly connected to the rest of the Muslim world.

This conference aims to situate Indonesian Islam in the global context, and to compare Islamic thinking and institutions in Indonesia with their counterparts in the Middle East and elsewhere. Within the wide range of this broad issue, the conference aims to address following topics which include: Islamic educational system, the political system and Islamic political parties, Islamic movements, Islamic law and the judiciary, religious elite and 'ulama, and gender issues.

The ultimate question to be answered is whether specific Indonesian solutions to particular Islamic issues in society contribute to the development of Islamic discourse in the Muslim world at large. More than one hundred scholars work on various research fields from Indonesia, Malaysia, Japan, Netherlands, Australia, and the U.S, attended this seminar.

Indonesia experiences a complex process of societal and political transformations, from a Dutch colony into a totalitarian regime evolving into a democratic state. Since 1998, Indonesia has begun a political transition through a reform which toppled Soeharto authoritarian 
regime. After three peaceful multiparty elections, since 1998, Indonesia is a successful example of Muslim-majority country that democratized. Thus, Indonesia's transition to democracy is evidence that Islam, as a religion and culture, is compatible with democracy. It countered some scholars' thesis that Islam is incompatible with democracy and has difficulty to avoid the autocratic government.

Many scholars have positive outlooks on Indonesian Islam. They argue that Islamic associations, groups, parties and individuals have given the significant role for the transformations of Indonesian politics. Indonesian Islam is different because of the contribution that it has given to socio-political transformations that Indonesia has undergone, especially in its support to democratic system instead of an Islamic state. Indonesia today is recognised as the third-largest democratic country in the world, after the United States and India, and the most democratic Muslim-majority country.

Then, whether Indonesian Islam is different from, at least, the Muslim countries in the Middle East and North Africa, was being discussed by scholars who participate in the seminar. Some of them offer their interesting views as describes below.

Professor Robert W. Hefner, an anthropologist from Boston University, who has written a number of books on Indonesian Islam credited Indonesia's Islamic organizations such as Nahdlatul Ulama (NU) and Muhammadiyah (with approximately 80 million and 14 million members respectively) for their roles in Indonesia's societal transformation. This according Professor Hefner what has made Indonesia's Islam is different. Their social activities, such as establishing schools, hospitals, orphanages and other social institutions, have set examples for how to balance Islamic principles, democracy and nationbuilding. Their activists have also been engaged in activities such as an anti-corruption movement, creating good governance, and helping develop public policy and budgeting in local governments.

Some scholars, for example, give their credits to Indonesia's cultural values to avoid conflict. Indonesian scholar Professor Taufik Abdullah says that the large sizes of Islamic organisations in Indonesia, instead of being splintered into smaller organisations, have made Indonesian Muslims appear more unified, adopting popular, inclusive religious interpretations as they avoid religious-based controversies or conflict.

Another scholar, Kees van Dijk of Leiden University, discovered 
three Indonesian types of Islam. The one is Indonesian Islam that has similarities with Islam in the whole Islamic world, and the second is Indonesian Islam that has a different manifestation and uniqueness. However, Kees said that the majority of Indonesian Muslims can be found between these two types, namely moderate, and that is the best manifestation. In addition, an Islamic scholar from Indonesia, Azyumardi Azra, says that Muslims in Indonesia emphasise the accommodative nature of Islam, which is why they easily accept democracy, human rights and other relatively new ideas.

The Indonesian experiences, as those scholars observed, offer two insights for emerging democracies in the Muslim world. First, Muslim civil society organisations can play active roles in strengthening democratic states. Second, the diversity within Islam should be seen as a strength so as to Muslims became familiar with societal differences and accept changes, and inspire not only individual piety and political ideals, but also the type of humanitarian initiatives necessary for nationbuilding.

Testriono is a researcher at PPIM UIN Jakarta. 


\section{حقون الطبعة محفوطة عنوان المر انسلة:}

Editorial Office:

STUDIA ISLAMIKA, Gedung Pusat Pengkajian Islam dan Masyarakat (PPIM) UIN Jakarta, Jl. Kertamukti No. 5, Pisangan Barat, Cirendeu, Ciputat 15419, Jakarta, Indonesia. Phone: (62-21) 7423543, 7499272, Fax: (62-21) 7408633; E-mail: studia@ppim.or.id or studia.ppim@gmail.com. Website: www.ppim.or:id

$$
\begin{aligned}
& \text { فيمة الإنشثز الك خاز ج إندو نبسيا: }
\end{aligned}
$$

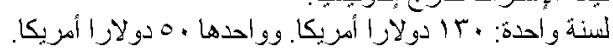

$$
\begin{aligned}
& \text { و القبمة لا يشنسل فيها نكليف الإرسال } \\
& \text { رقم الحنساب: }
\end{aligned}
$$

$$
\text { داخل إندو نيبنيبا (روبية): }
$$

PPIM, Bank Mandiri Jakarta, Indonesia No Rek: 128-00-0105080-3 (Rp).

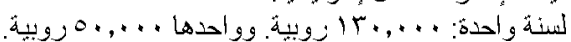

$$
\begin{aligned}
& \text { والقِمة لا بشنتل فيها تكليف الإرسال }
\end{aligned}
$$

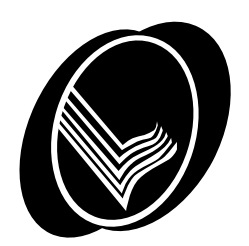




\section{ستئوديا إسلاميكا}

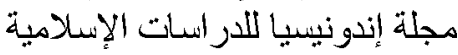

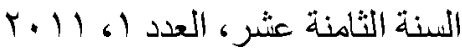

هيئة التحرير:

م. قريش شهاب (جامعة شريف هداية الله الإسلامية الحكومية جاكر تا) توفيق عبد الله (المركز الإندو نيسي للعلوم) نور أ. فاضل لوبيس (الجامعة الإسلامية الحكومية سومطرة الشمالية)

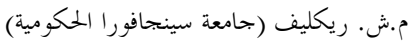
مارتين فان برونيسين (جامعة أتريخة)

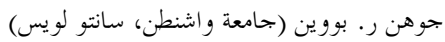

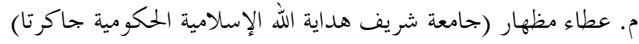

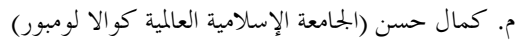
مُ ب. ب. هو كير (جامعة أستراليا الحكومية كانبيرا) فر كنيا م. هو كير (جامعة أستر اليا المكومية كانبيرا)

$$
\begin{aligned}
& \text { رئيس التحرير: } \\
& \text { أزيوماردي أزرا } \\
& \text { الخحرون: } \\
& \text { سيف البحاني } \\
& \text { جمهاري } \\
& \text { جاجات برهان الدين } \\
& \text { عمان فتح الرممن } \\
& \text { علي منحنف الرحن } \\
& \text { إسماتو رافي } \\
& \text { دينا أفرينطي } \\
& \text { مساعد هيئة التحرير: } \\
& \text { تسطيريونو } \\
& \text { محمد نداء فضلان } \\
& \text { مر اجعة اللغة الإبحليزية: } \\
& \text { ميليسا كروش الإكلزبة } \\
& \text { مر اجعة اللغة العربية: } \\
& \text { الرازي هاشم الرمبة } \\
& \text { تصميم الغلاف: } \\
& \text { س. برنكا }
\end{aligned}
$$

ستوديا إسلاميكا (ISSN: 0215-0492) هي مبحة دورية يصدرها مركز البحوث الإسلامية



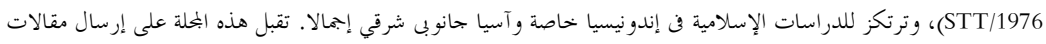

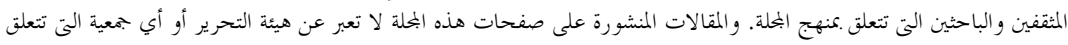

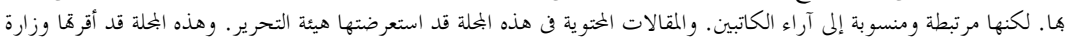




\section{لالتوديا السل||سليا}




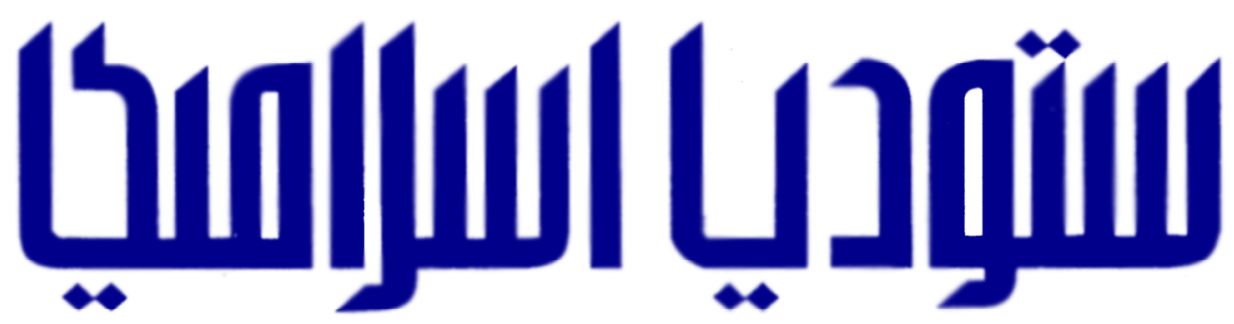

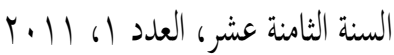

بجلة إندونيسية للدراسات الإسلامية

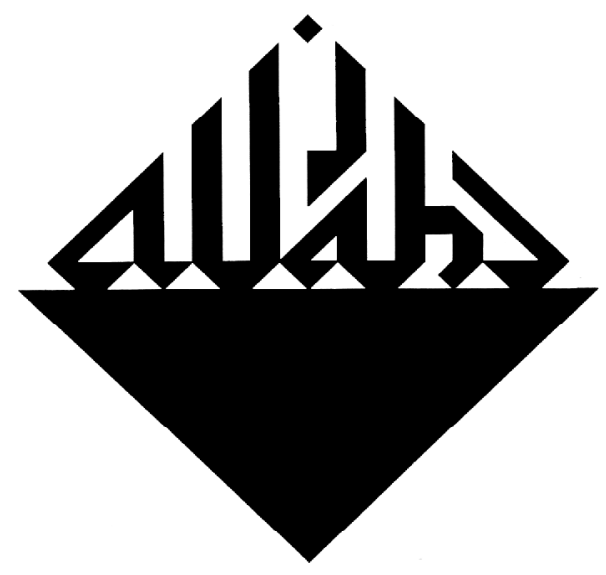

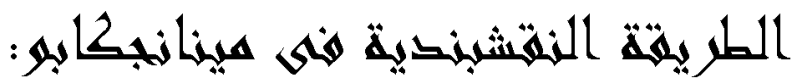

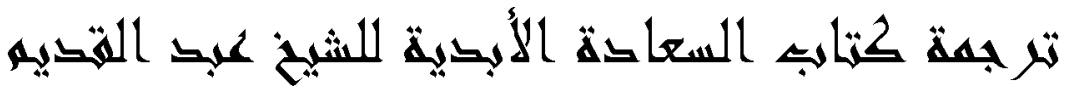

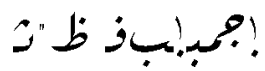

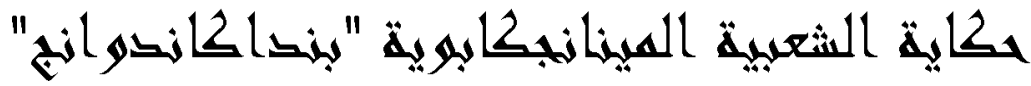

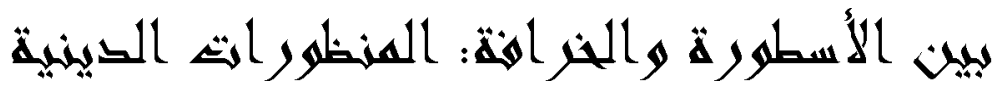
إبغ.غ 